\title{
Chapter 2 \\ Diaspora Policies, Consular Services and Social Protection for Austrian Citizens Abroad
}

\author{
Anita Heindlmaier
}

\subsection{Introduction}

Austria is engaged in a broad range of diaspora policies: from culture, citizenship matters, over economic policies to social protection. Yet, this chapter will demonstrate that Austrian policies towards citizens abroad focus on access to information, as "help for self-help", and as guaranteeing a link to Austria(n culture), on voting rights as well as social protection in extreme cases of hardship.

In a first section hereafter, figures and characteristics on Austrians abroad will be presented, followed by an overview of Austrian domestic institutions and those abroad dealing with the matters of Austrians abroad. Subsequently, the key policies such as voting rights will be outlined. It will be demonstrated that especially citizenship matters and voting rights have had a high priority amongst Austrians abroad, leading to the fact that voting rights have been continuously extended within the past 30 years.

The second section of this chapter will focus on Austrian diaspora policies and social protection. It will be made clear that Austrian diaspora policies thus have to be grasped in the context of the Second World War and the Anschluss. Austria introduced several special policies for persons who suffered under the Nazi regime.

\footnotetext{
A. Heindlmaier $(\bowtie)$

Department of Political Science, Salzburg Centre of European Union Studies, University of

Salzburg, Salzburg, Austria

e-mail: anita.heindlmaier@sbg.ac.at
} 


\subsection{Diaspora Policy Infrastructure and Key Policies}

The first section begins with an overview of the Austrian diaspora and its relations with the homeland (2.2.1) as well as Austrian diaspora infrastructure (2.2.2). Afterwards, Austrian key engagement policies such as voting rights will be discussed (2.2.3).

\subsubsection{The Austrian Diaspora and Its Relations with the Homeland}

Emigration is not a new phenomenon in Austria. Yet, while only few Austrians emigrated before 1876, the economic situation and disparities caused millions of citizens to leave Austria between 1876 and the First World War. A high share of these persons settled in the US and in Canada. Between the two World Wars, emigration was even furthered by the Austrian government, as a measure to combat the economic crisis and unemployment. During the Nazi regime, in particular Jewish citizens, but also certain politicians, intellectuals or artists left respectively had to leave the country, whereof most went to the UK. This specific history explains several diaspora policies towards Austrians abroad as will be elaborated later.

After the Second World War, migration to the US and Canada declined, whereas that to the neighbouring countries, in particular Germany and Switzerland, increased. The latter migration has been largely labour-driven (Neyer 1995). According to the Austrian Federal Ministry for Europe, Integration and Foreign Affairs (FMEIA), around 565,000 Austrians live abroad nowadays. The majority of them reside in Germany (257,000 Austrians), followed by Switzerland $(65,000)$, the US $(35,000)$, and the UK $(25,000) .{ }^{1}$ The numbers are estimations, as Austrians abroad do not have to register since signing up with the registration service for Austrians abroad (Registrierung für Auslandsösterreicher) is done on a voluntary basis.

Austrians abroad have a strong identity-based link to their country of origin. According to a survey conducted by the FMEIA and the Worldwide Association of Austrian Associations Abroad in 2009, the key priorities of Austrians abroad are by far the following three: citizenship matters, questions about pension and insurance related to Austria, and the participation in Austrian elections. Return to their country of origin, social support abroad and information about Austria share the fourth place. With regard to the top priority of citizenship matters, a survey on this topic from 2005 demonstrates that the retention of the Austrian citizenship when obtaining another one, the passing on of the Austrian citizenship to children, and the

\footnotetext{
${ }^{1}$ Bundesministerium für Europa, Integration und Äußeres (2019). Treffpunkt AuslandsösterreicherInnen. https://www.bmeia.gv.at/reise-aufenthalt/leben-im-ausland/treffpunktauslandsoesterreicherinnen/. Accessed 24 February 2019.
} 
facilitation of dual citizenship, are of particular concern. ${ }^{2}$ These interests of Austrians can, to some extent, explain the current shape of the country's diaspora policies.

\subsubsection{Diaspora Infrastructure}

Austria has embassies in around 80 countries of the worlds and undertakes diplomatic relations to 196 countries (ambassadors are also accredited in countries where Austria does not have an embassy). Besides, Austria has generate consulates in regions and countries where a high number of Austrians live respectively which have close cultural or economic relations to Austria: Brazil, China, Germany, France, Italy, Turkey, and the US. Austrian missions offer also mobile consular services to Austrians abroad who are unable to present themselves to the consulate because of their age or because of a sickness. ${ }^{3}$ More than 300 honorary consulates in more than 130 countries of the world complement the Austrian consular network: honorary consuls are persons who, voluntarily, take on the interest of Austria and are a first contact point to Austrians (abroad) in regions where no mission which enjoys diplomatic status exists. Some of them forward documents to the competent authorities, some of them are even entitled to issue documents themselves such as life certificates (a list of all representations can be found on the website of the FMEIA) ${ }^{4}$

Besides these institutions abroad, a special department within the Federal Ministry for Europe, Integration and Foreign Affairs in Vienna is dedicated to Austrians abroad, the Office for Austrians Abroad and Digital Applications of Consular Citizens' Advice (Büro für AuslandsösterreicherInnen und digitale Anwendungen in der konsularischen BürgerInnenbetreuung, section IV.3 FMEIA). This office takes charge of any matters that concern Austrians abroad - inter alia their voting rights, questions related to assets abroad or in Austria as well as labour

\footnotetext{
${ }^{2}$ Bundesministerium für Europa, Integration und Äußeres (2019). Themen. https://www.bmeia. gv.at/reise-aufenthalt/leben-im-ausland/treff. Accessed 24 February 2019.

${ }^{3}$ Bundesministerium für Europa, Integration und Äußeres (2019). Life Certificate. https://www. bmeia.gv.at/en/travel-stay/living-abroad/documents-civil-status-family/life-certificate/. Accessed 24 February 2019; Pensionsversicherungsanstalt (2018). Lebensbestätigung. http://www.pensionsversicherung.at/portal27/pvaportal/content/contentWindow? contentid=10007.707694\&act ion=2. Accessed 24 February 2019.

${ }^{4}$ Bundesministerium für Europa, Integration und Äußeres (2019). Directory of Austrian Representations. https://www.bmeia.gv.at/en/embassies-consulates/search-for-austrian-representations/. Accessed 24 February 2019; Bundesministerium für Europa, Integration und Äußeres (2019). Welche Arten von österreichischen Vertretungen gibt es? https://www.bmeia.gv.at/ botschaften-konsulate/suche-nach-oesterreichischen-vertretungen/welche-arten-von-vertretungen-gibt-es/. Accessed 24 February 2019; Bundesministerium für Europa, Integration und Äußeres (2019). Austrian Representations. https://www.bmeia.gv.at/en/embassies-consulates/search-foraustrian-representations/. Accessed 24 February 2019.
} 
law and social law matters - and forwards their requests to the competent Ministries, in case of citizenship matters for instance the Ministry of the Interior. It further collaborates with the Worldwide Association of Austrian Associations Abroad (Auslandsösterreicher-Weltbund, AÖWB), for instance when identifying the priorities of Austrians abroad, and supervises the fund for Austrians abroad (see below). ${ }^{5}$

All nine Austrian regions have a department within their government which is inter alia concerned with Austrians abroad. ${ }^{6}$ Several regions even have a special section exclusively dedicated to Austrians abroad, for instance Styria. Its Office for Styrians abroad (Büro für Auslandssteirer) seeks to strengthen the ties to the region via cultural, personal, economic, sports and touristic contacts and projects. ${ }^{7}$

Out of the five parties in the Lower Chamber of the Austrian Parliament, the Nationalrat, only NEOS - The New Austria and Liberal Forum (NEOS - Das Neue Österreich und Liberales Forum) has a special section for Austrians abroad. In addition to the regional groups of the nine regions within Austria, this party has a group for Austrians abroad, as "10th region" of Austria (NEOS $X-10$ th region). ${ }^{8}$ This section is led by a small team on a voluntary basis. NEOS also actively encourages Austrians abroad to stand as candidates in national legislative elections. In order to do so, they do not have to be proposed by a party committee but can simply decide themselves to run for the preliminary online election in order to receive a place on the list of NEOS.

As an umbrella association, the Worldwide Association of Austrian Associations Abroad (Auslandsösterreicher-Weltbund, AÖWB) with its head office in Vienna pools and articulates the interests of Austrians abroad, thereby being in close contact with the FMEIA, and provides information about Austria and a link to Austria(n culture) to Austrians abroad. This association is, to a large share, funded by the FMEIA and the Austrian regions. It holds conferences and meetings abroad as well as in Austria (one Weltbund-conference per year in Austria), publishes the quarterly journal Rotweissrot, and runs the platform Austrians.org, a social network where Austrians (abroad) and friends of Austria can interact, thus establish and maintain contacts and share information. On the website of the AÖWB, Austrians abroad can search for the associations in their specific country of residence. ${ }^{9}$ Amongst the nine Austrian regions, only Burgenland has a special association for its citizens abroad, the Burgenland Community (Burgenländische Gemeinschaft),

\footnotetext{
${ }^{5}$ Bundesministerium für Europa, Integration und Äußeres (2019). Geschäftseinteilung. Abteilung IV.3. https://www.bmeia.gv.at/das-ministerium/geschaeftseinteilung/organisation/show/abteilungiv3/. Accessed 24 February 2019.

${ }^{6}$ For an overview: Auslandsösterreicher-Weltbund (2004). Information - Adressen. http://www. weltbund.at/service_adressen.asp. Accessed 24 February 2019.

${ }^{7}$ Land Steiermark - Amt der Steiermärkischen Landesregierung (2019). Mission. http://www.verwaltung.steiermark.at/cms/beitrag/10183755/5051212. Accessed 24 February 2019.

${ }^{8}$ NEOS (2019). NEOS X - 10. Bundesland. https://international.neos.eu/. Accessed 24 February 2019.

${ }^{9}$ Auslandsösterreicher-Weltbund (2016). Herzlich Willkommen beim AuslandsösterreicherWeltbund. http://www.weltbund.at. Accessed 24 February 2019.
} 
whose aim is to maintain and strengthen the ties to Burgenland, promote the interests of Burgenländers abroad and to organize events. It publishes the journal Burgenländische Gemeinschaft. ${ }^{10}$

\subsubsection{Key Engagement Policies}

As consular policies are traditionally a central feature of sending states' engagement with citizens abroad, it is noteworthy that —unlike the majority of other European states-Austria did not have any national legal basis for consular services until recently. The latter were solely based upon the Vienna Convention on Consular Relations and there was only an internal guideline on consular and diplomatic services of the FMEIA. Recently, the transposition of Directive (EU) 2015/637 of 20 April 2015 on the coordination and cooperation measures to facilitate consular protection for unrepresented citizens of the Union in third countries and repealing Decision 95/553/EC was taken as grounds for changing the situation. Besides the transposed Directive, the - at the time of the chapter envisaged - Federal Law on the exercise of consular functions (Bundesgesetz über die Wahrnehmung konsularischer Aufgaben) intends to contain sections on consular tasks which codify the already existing practices and clarify the (non-)duties of Austrian representations. For instance, its draft explains that Austrians staying abroad do not have any legal right to financial aid by Austrian missions. ${ }^{11}$

In general, consular support is considered as "help for self-help" meaning that consulates (and the FMEIA) provide first support, information and contacts so that Austrians abroad can "organize appropriate assistance" (CARE Project 2010: 54). In terms of basic protection policies, Austrian diaspora institutions provide first information and contacts so that Austrians abroad can arrange for further assistance. As I shall discuss in Sect. 2.3, additional actions by home country institutions can be taken in cases of emergency and hardship via the Fund for the Support of Austrian Citizens Abroad, and a Christmas campaign for Austrian citizens abroad where (in-kind) donations are collected and distributed amongst Austrians abroad who are in need. Moreover, Austrians abroad who are of old age or seriously ill can be taken over into care in Austria. Finally, Austria has also concluded a number of social security agreements that respond to specific social protection needs of citizens abroad (see Sect. 2.3).

\footnotetext{
${ }^{10}$ Bundesministerium für Europa, Integration und Äußeres (2019). Associations representing Austrians abroad. https://www.bmeia.gv.at/en/travel-stay/living-abroad/meeting-point-austriansabroad/associations-representing-austrians-abroad/. Accessed 24 February 2019.

${ }^{11}$ Nationalrat (2018). 106/ME XXVI. GP - Ministerialentwurf - Gesetzestext. https://www.parlament.gv.at/PAKT/VHG/XXVI/ME/ME_00106/fname_724513.pdf. Accessed 24 February 2019; Nationalrat (2018). 106/ME XXVI. GP - Ministerialentwurf - Vorblatt und Wirkungsorientierte Folgenabschätzung. https://www.parlament.gv.at/PAKT/VHG/XXVI/ME/ME_00106/fname_ 724514.pdf. Accessed 24 February 2019.
} 
For further administrative tasks, e.g. for issuing passports or certifying documents, costs must be covered by citizens. The respective costs are regulated in the Consular Fees Act (Konsulargebührengesetz 1992). Moreover, there is a special regulation that lays down how to certify documents (Verordnung des Bundesministers für Auswärtige Angelegenheiten vom 16. März 1984 betreffend Beglaubigungen durch österreichische Vertretungsbehörden im Ausland). In order to facilitate the interaction of Austrian citizens with Austrian authorities, a mobile phone signature was introduced. This signature serves as a "virtual ID card" and allows users, for instance, to request authorities to issue documents or to apply for a ballot, at least within the European Union (EU). The mobile phone signature needs to be activated which can be undertaken in registration centres in Austria but also in eight Austrian representations within Europe. ${ }^{12}$

On its website, the FMEIA lists some advices on how to make adequate preparations when moving abroad. These advices contain administrative formalities and provisions for social protection (see details on the latter in 2.3) ${ }^{13}$ First of all, Austrians abroad are encouraged to sign up with the registration service for Austrians abroad (Registrierung für AuslandsösterreicherInnen) of the FMEIA, what can be undertaken online or with the relevant Austrian representation. Being registered guarantees that the Austrian missions as well as the Ministry can contact Austrians abroad in case of emergency and can provide information which may be useful for the stay abroad. Moreover, the representation can inform them about political events or reforms in Austria and invite them to events which it organizes, for instance receptions on the occasion of the Austrian National Day. ${ }^{14}$

One of the major Austrian policies towards citizens abroad concerns electoral rights. Since 1990, Austrians abroad are allowed to vote in elections at the national level, i.e. presidential elections, legislative elections (Lower House) and EU elections, as well as in referenda. They had, however, to fight for these rights as well as for facilitated procedures: While Austrians abroad had already claimed the right to vote for quite some time, it was only in 1989 that the Austrian Constitutional Court held that the Austrian law on elections (WählerevidenzG 1973) violated the constitution by excluding persons who did not reside in Austria from the right to vote. ${ }^{15}$ In 1990, Austrians abroad had thus, for the first time, the right to take part in national

\footnotetext{
${ }^{12}$ The representations in Berlin, Bern, Brussels, London, Madrid, Milan, Munich and Stockholm can activate the signature. Bundesministerium für Europa, Integration und Äußeres (2019). HandySignatur (mobile phone signature). https://www.bmeia.gv.at/en/travel-stay/living-abroad/meetingpoint-austrians-abroad/handy-signatur-mobile-phone-signature/. Accessed 24 February 2019.

${ }^{13}$ Bundesministerium für Europa, Integration und Äußeres (2019). Übersiedlung. https://www. bmeia.gv.at/reise-aufenthalt/leben-im-ausland/uebersiedlung/. Accessed 24 February 2019; Bundesministerium für Europa, Integration und Äußeres (2019). Übersiedlung ins Ausland. https:// www.bmeia.gv.at/reise-aufenthalt/leben-im-ausland/uebersiedlung/uebersiedlung-ins-ausland/. Accessed 24 February 2019.

${ }^{14}$ Bundesministerium für Europa, Integration und Äußeres (2019). Registrierung. https://www. bmeia.gv.at/reise-aufenthalt/leben-im-ausland/treffpunkt-auslandsoesterreicherinnen/registrierung/. Accessed 24 February 2019.

${ }^{15}$ Austrian Constitutional Court, judgment of 16 March 1989, G218/88.
} 
elections (Chlestil 2013). In general, parties' views on extended rights and facilitated procedures for Austrians abroad differ. It is in particular the Austrian People's Party (Österreichische Volkspartei, ÖVP), beneficiary of votes of Austrians abroad, that stands up for these issues. Recently, it demanded a further facilitation, the introduction of e-voting for Austrians abroad (Mittelstaedt 2016).

In order to be eligible to vote, Austrians abroad need to meet the general criteria: they have to be at least 16 years old and must not be excluded from the right to vote (e.g. while serving a prison term). As an additional precondition, Austrians residing abroad need to file an application to the relevant municipality (if applicable the last place of residence) in order to be taken up into the (EU) electoral register ((Europa-) Wählerevidenz; one form) respectively in order to stay registered as a voter. When signing up for the EU electoral register, Austrians abroad also need to make a formal declaration. The application can be filed at any time, also online or via the mobile phone signature (if applicable). The registration is valid for a period of 10 years and has to be renewed afterwards. Austrians residing abroad are notified shortly before the expiry by the relevant municipality.

Austrians abroad are informed about upcoming elections by their competent municipality. In order to be able to vote, they need to request a ballot (Wahl-/ Stimmkarte) in person or in writing (or via the mobile phone signature if applicable) with the relevant municipality in due time before the respective election. They can also request the ballot via the Austrian representative authority, or they can request an automatic sending for a period of 10 years. In order to make their vote count, Austrians abroad can then send the ballot via mail from abroad; the card has to arrive by 5 p.m. on election day. At least 6 days (respectively 9 days if outside of the European Economic Area/Switzerland) before election day, Austrians abroad can also submit their ballot to an Austrian representative authority which then forwards it to the respective municipality. If being present in Austria, Austrians abroad can also vote in person at the polling station where they are registered on election day. ${ }^{16}$ Reports however show that Austrians are de facto partly excluded from making their vote count because ballots sent via post tend to arrive after election day. ${ }^{17}$

Austrians abroad can also stand as candidates in national elections. There are no restrictions with regard to the time spent abroad or the requirement of a (previous) residence in Austria. Except from the registration before the relevant deadline,

\footnotetext{
${ }^{16}$ Bundesministerium für Europa, Integration und Äußeres (2019). Wahlrecht. https://www. bmeia.gv.at/reise-aufenthalt/leben-im-ausland/wahlen/wahlrecht/. Accessed 24 February 2019; Bundesministerium Digitalisierung und Wirtschaftsstandort (2019). Eintragung in die (Europa-) Wählerevidenz - Auslandsösterreicher. https://www.help.gv.at/Portal.Node/hlpd/public/ content/48/Seite.480403.html. Accessed 24 February 2019; Bundesministerium Digitalisierung und Wirtschaftsstandort (2019). Stimmabgabe im Ausland. https://www.help.gv.at/Portal.Node/ hlpd/public/content/32/Seite.320510.html. Accessed 24 February 2019; Bundesministerium Digitalisierung und Wirtschaftsstandort (2019). Wahlkarte/Stimmkarte. https://www.help.gv.at/ Portal.Node/hlpd/public/content/32/Seite.320520.html\#Wahlkarte. Accessed 24 February 2019.

${ }^{17}$ OSCE (2018). Republic of Austria. Early Parliamentary Elections 15 October 2017. OSCE/ ODIHR Election Assessment Mission Final Report. https://www.osce.org/odihr/elections/austria/ 370866?download=true. Accessed 24 February 2019.
} 
Austrians abroad need to fulfil the same conditions such as Austrians residing in Austria. ${ }^{18}$

Since 2007, Austrian regions can allow Austrians abroad to vote in regional parliamentary elections. Precondition is that Austrians abroad had their main residence in the region before and that they transferred their main residence abroad less than 10 years prior to the election. Only three regions make use of this possibility to date: Lower Austria, Tyrol and Vorarlberg. As an example, the rules and procedure for the parliamentary elections in Tyrol will be laid down in the following.

Tyroleans abroad need to be, such as residents, at least 16 years old and must not be denied the right to vote (e.g. while serving a prison term). As an additional precondition, Tyroleans abroad need to file an application with the relevant municipality of their last place of residence in Tyrol in order to be taken up into the regional electoral register (Auslandstirolerevidenz), before the respective deadline of the election. The registration is valid for a maximum period of 10 years. The modalities to cast a ballot correspond in general to those of the national elections (however, Tyroleans abroad can only cast their ballot at any polling station within the region). They are under the same conditions as residents eligible to run as candidates. ${ }^{19}$ In Lower Austria and Burgenland, also persons with a secondary residence are allowed to vote. This makes it easier for Austrians abroad to vote (Stern and Valchars 2013).

Looking at other consular tasks, Austrian missions are in general the competent authorities that issue personal documents for Austrians abroad, such as passports, ID cards, or certificates of citizenship. ${ }^{20}$ With the introduction of the central civil registry (Zentrales Personenstandsregister) in 2014, they can also issue civil status documents (Personenstandsurkunden), i.e. birth, marriage and death certificates, since they have obtained access to the necessary information and thus no longer have to receive such documents from authorities in Austria. ${ }^{21}$ In case of the death of an Austrian abroad, the Austrian representation can, if necessary, take preliminary administrative measures to secure the estate, e.g. sealing off of property. ${ }^{22}$

\footnotetext{
${ }^{18}$ They may not be excluded from the right to vote (e.g. while serving a prison term) and be at least 18 years old with regard to the legislative election (Lower House) and the EU election respectively 35 years old with regard to the presidential election. Bundesministerium für Europa, Integration und Äußeres (2019). Wahlrecht. https://www.bmeia.gv.at/reise-aufenthalt/leben-im-ausland/ wahlen/wahlrecht/. Accessed 24 February 2019.

${ }^{19}$ Bundesministerium Digitalisierung und Wirtschaftsstandort (2019). Aktives Wahlrecht Landtagswahl in Tirol am 25. Februar 2018. https://www.help.gv.at/Portal.Node/hlpd/public/content/32/Seite.320745.html. Accessed 24 February 2019; Bundesministerium für Europa, Integration und Äußeres (2019). Wahlrecht. https://www.bmeia.gv.at/reise-aufenthalt/leben-imausland/wahlen/wahlrecht/. Accessed 24 February 2019.

${ }^{20}$ Bundesministerium für Europa, Integration und Äußeres (2019). Documents, civil status, family. https://www.bmeia.gv.at/en/travel-stay/living-abroad/documents-civil-status-family/. Accessed 24 February 2019.

${ }^{21}$ Bundesministerium für Europa, Integration und Äußeres (2019). Living abroad. https://www. bmeia.gv.at/en/travel-stay/living-abroad/. Accessed 24 February 2019.

${ }^{22}$ Bundesministerium für Europa, Integration und Äußeres (2019). Death of an Austrian citizen abroad. https://www.bmeia.gv.at/en/travel-stay/service-for-citizens/emergencies-abroad/death-ofan-austrian-citizen-abroad. Accessed 24 February 2019.
} 
As concerns economic policies concerning citizens abroad, Austria has been much less active than other states as it has only signed a range of agreements with other countries to avoid double taxation of income and capital. ${ }^{23}$ At the cultural level, on the contrary, Austria has 29 Austrian Cultural Forums (Kulturforen) in 27 countries (that can be considered as "Embassies for culture") designed to guarantee cultural exchanges. These forums organize cultural as well as academic projects (often in collaboration with local institutions) and support Austrian cultural practitioners in providing contacts. ${ }^{24}$ Moreover, there are eight Austria Institutes (Österreich Institute) which do not exclusively target Austrian citizens abroad. These institutes offer German classes and seek to ensure cultural exchanges. ${ }^{25}$ Austrians abroad have also access to their German classes but need to bear the costs themselves, similarly to foreigners.

\subsection{Diaspora Policies and Social Protection in Austria}

In line with its approach of "help for self-help", Austrian policies for citizens abroad in the area of social protection consist primarily of providing information. For instance, information about relevant social security agreements between Austria and other countries is given. Yet, in cases of hardship, Austrians abroad can apply for financial assistance or, in case they are old or seriously ill and can no longer provide for themselves, for repatriation to Austria. This section starts by giving a brief overview of the information strategies regarding the social rights of Austrians abroad and of consular interventions in-cash or in-kind, followed by an analysis of five main policy areas: unemployment, health care, pensions, family-related benefits, and economic hardship.

Austrians abroad or those who plan to go abroad find basic information about social protection and contacts on the websites of the FMEIA and the relevant Austrian representation. ${ }^{26}$ For further information, they can contact the consulates or the FMEIA, or directly the competent (social security) authority. Besides the EU legal framework, Austria has signed several bilateral agreements with other countries regarding social security. These agreements generally set the rule that nationals of the two countries should be treated equally with regard to social security.

\footnotetext{
${ }^{23}$ Bundesministerium für Finanzen (2017). The Austrian Tax Treaty Network. https://english.bmf. gv.at/ taxation/The-Austrian-Tax-Treaty-Network.html. Accessed 24 February 2019.

${ }^{24}$ Bundesministerium für Europa, Integration und Äußeres (2019). Welche Arten von österreichischen Vertretungen gibt es? https://www.bmeia.gv.at/botschaften-konsulate/suche-nach-oesterreichischen-vertretungen/welche-arten-von-vertretungen-gibt-es/. Accessed 24 February 2019.

${ }^{25}$ Österreich Institut (2019). About us. https://www.oesterreichinstitut.at/information-in-english. Accessed 24 February 2019.

${ }^{26}$ Bundesministerium für Europa, Integration und Äußeres (2019). Gesundheit und Soziales. https://www.bmeia.gv.at/reise-aufenthalt/leben-im-ausland/gesundheit-und-soziales/. Accessed 24 February 2019.
} 
In particular, they intend to secure rights of persons who have worked in both countries, e.g. by adding up the insurance periods in both countries for benefit entitlement (for further details see subsections below) ${ }^{27}$ Here again, both the websites of the FMEIA and of Austrian representations link to the relevant website of the Ministry of Social Affairs which lists these agreements and thus provides first further information. ${ }^{28}$ As a matter of good practice, Austria encourages persons to take precautions for their residence abroad and take out insurance beforehand as well as arrange for documents such as living wills or health care proxies in the event that they are no longer able to manage their own affairs. ${ }^{29}$

Several consular interventions in-cash or in-kind rather concern Austrians on vacation, but may also be used by Austrians residing abroad: In case of loss or theft of monetary assets and if transfers via Western Union are not possible, Austrians (abroad) can make a deposit with the FMEIA, by transferring money from either the own Austrian bank account or the bank account of relatives or friends to which the Austrian representation establishes the contact. If this is not possible, the Austrian representation may grant a repatriation loan that the person has to repay later. Precondition is, however, that the person is still registered in Austria and that the emergency situation is not the fault of the person..$^{30}$ In case of accident or death, consulates can inform relatives and provide further contacts. And representations can assist in arranging for the repatriation transportation of ill, injured and deceased Austrians. The expenses have to be taken over by relatives and (if available) an insurance.

For Austrians abroad, a special fund was established in 1967, the Fund for the Support of Austrian Citizens Abroad (see details below, Sect. 2.3.5). And with regard to Austrians abroad of old age or those who are seriously ill and who are no longer able to provide for themselves, Austria has a special repatriation policy, Austrians' abroad return to Austria in special emergencies (see details below, Sect. 2.3.2.). ${ }^{31}$

\footnotetext{
${ }^{27}$ Bundesministerium für Europa, Integration und Äußeres (2019). Agreements on social security https://www.bmeia.gv.at/en/travel-stay/living-abroad/gesundheit-und-soziales/agreements-onsocial-security/. Accessed 24 February 2019.

${ }^{28}$ Bundesministerium für Arbeit, Soziales, Gesundheit und Konsumentenschutz (2018). Zwischenstaatliche Beziehungen Österreichs im Bereich der sozialen Sicherheit auf einen Blick https://www.sozialministerium.at/cms/site/attachments/0/9/1/CH3434/CMS1470041431373/ abkommensuebersicht_1-3-18.pdf. Accessed 24 February 2019.

${ }^{29}$ Bundesministerium für Europa, Integration und Äußeres (2019). Gesundheit und Soziales. https://www.bmeia.gv.at/reise-aufenthalt/leben-im-ausland/gesundheit-und-soziales/. Accessed 24 February 2019.

${ }^{30}$ Bundesministerium für Europa, Integration und Äußeres (2019). Loss of cash https://www. bmeia.gv.at/en/travel-stay/service-for-citizens/emergencies-abroad/loss-of-cash/. Accessed 24 February 2019.

${ }^{31}$ Bundesministerium für Europa, Integration und Äußeres (2019). AÖ Rückkehr nach Österreich in besonderen Notlagen. https://www.bmeia.gv.at/reise-aufenthalt/leben-im-ausland/gesundheitund-soziales/aoe-rueckkehr-nach-oesterreich-in-besonderen-notlagen/. Accessed 24 February 2019.
} 
Having outlined the general policies with regard to social protection, the subsequent subsections will deal with specific areas of unemployment, health care, pension, family-related benefits and economic hardship.

\subsubsection{Unemployment}

Beyond the European framework that guarantees access to unemployment benefits to Austrians who move abroad, the intervention of Austrian authorities in the area of unemployment is rather limited. First information about unemployment benefits abroad can be found on the websites of the FMEIA (short information and links to further websites), the Ministry for Social Affairs as well as the Austrian Employment Service (Arbeitsmarktservice, AMS). With regards to the ability to export unemployment benefits, the general rule is that Austrians moving abroad cannot draw Austrian unemployment benefits abroad. Austrians who go abroad, inside and outside the EU, in order to seek for employment can be allowed to export their unemployment benefits for a maximum period of 3 months. They need to file a request of indulgence (Nachsichtsansuchen) with their regional branch of the Austrian Employment Service in which they list the reasons and, if necessary, submit confirmations..$^{32}$

As concerns the conditions of access to unemployment benefits in non-EU destination countries, few bilateral social security agreements allow it. For instance the agreement between Austria and Serbia (Abkommen zwischen der Republik Österreich und der Republik Serbien über Soziale Sicherheit) provides for the option of cumulating contribution periods, in case a person was insured at least 26 weeks within the last 12 months. On the contrary, agreements with countries such as the US, Canada or Australia, where many Austrians abroad reside, do not contain provisions which ensure an agglomeration of contribution periods.

\subsubsection{Health Care}

As first basic information regarding health abroad, the Federal Ministry for Europe, Integration and Foreign Affairs lists health risks and security risks in particular countries on its website - for both Austrian tourists and Austrians abroad. ${ }^{33}$ Moreover, as already held earlier, the FMEIA encourages Austrians to provide for

\footnotetext{
${ }^{32}$ Arbeitsmarktservice Österreich (2019). Leistungsexport. http://www.ams.at/ratgeber-arbeitsuchende/anspruch-export. Accessed 24 February 2019.

${ }^{33}$ Bundesministerium für Europa, Integration und Äußeres (2019). Reiseinformation. https://www. bmeia.gv.at/reise-aufenthalt/reiseinformation. Accessed 24 February 2019; Bundesministerium für Europa, Integration und Äußeres (2019). Reisewarnungen. https://www.bmeia.gv.at/reise-aufenthalt/reisewarnungen/. Accessed 24 February 2019.
} 
their residence abroad and unforeseen situations: Austrians should arrange for living wills, health care proxy, and insurance. ${ }^{34}$

Austrian representations maintain a network of trusted medical examiners abroad which can be found online or whose contact details can be obtained with the relevant Austrian representation. ${ }^{35}$ In case of emergency abroad and if persons do not receive help from any other organization, the relevant Austrian representation can assist in arranging treatment. Moreover, it can inform relatives and friends. Concerning Austrians imprisoned abroad, consulates can intervene if they face inadequate conditions, e.g. with regard to medical care. This is mostly applicable to Austrians who are on vacation abroad but may also be relevant for Austrians residing abroad. ${ }^{36}$

Health is part of some social security agreements between Austria and other countries. For instance the agreement with Serbia lays down that nationals having an insurance of one country can enjoy the same medical treatment as nationals in the other country. This may also concern Austrians who live there and draw the Austrian pension (and no pension in the country of residence): their treatment abroad is covered by the Austrian health insurance. ${ }^{37}$ Yet, the agreements with the US, Canada and Australia which are home to a high number of Austrians do not contain such rules. ${ }^{38}$

With regard to seriously ill Austrians residing abroad or those of old age who are no longer able to provide for themselves and who have no relatives that can help them and who thus find themselves in an extreme situation, Austria has a special repatriation policy, Austrians' abroad return to Austria in special emergencies (AÖ Rückkehr nach Österreich in besonderen Notlagen), former takeover into home care (Übernahme in die heimatliche Fürsorge). This policy may also be understood against the background of the Second World War when a lot of persons had to leave Austria. For being repatriated to Austria and placed in a hospital, Austrians abroad or (psychiatric) hospitals approach the respective representation and describe the

\footnotetext{
${ }^{34}$ Bundesministerium für Europa, Integration und Äußeres (2019). Gesundheit und Soziales. https://www.bmeia.gv.at/reise-aufenthalt/leben-im-ausland/gesundheit-und-soziales/. Accessed 24 February 2019.

${ }^{35}$ Bundesministerium für Europa, Integration und Äußeres (2019). Austrian Representations. https://www.bmeia.gv.at/en/embassies-consulates/search-for-austrian-representations/. Accessed 24 February 2019.

${ }^{36}$ Bundesministerium für Europa, Integration und Äußeres (2019). Emergencies abroad. https:// www.bmeia.gv.at/en/travel-stay/service-for-citizens/emergencies-abroad. Accessed 24 February 2019; Bundesministerium für Europa, Integration und Äußeres (2019). Sickness and accidents. https://www.bmeia.gv.at/en/travel-stay/service-for-citizens/emergencies-abroad/sickness-andaccidents/. Accessed 24 February 2019.

${ }^{37}$ Pensionsversicherungsanstalt (2019). Information für im Ausland lebende Pensionisten und Pensionistinnen. Wien: Pensionsversicherungsanstalt.

${ }^{38}$ Bundesministerium für Arbeit, Soziales, Gesundheit und Konsumentenschutz (2018). Zwischenstaatliche Beziehungen Österreichs im Bereich der sozialen Sicherheit auf einen Blick https://www.sozialministerium.at/cms/site/attachments/0/9/1/CH3434/CMS1470041431373/ abkommensuebersicht_1-3-18.pdf. Accessed 24 February 2019.
} 
special emergency situation. This information is forwarded to the FMEIA. It is carefully assessed whether repatriation would make sense, taking also into account whether the persons agree upon being taken to Austria and whether they still have any link to Austria, and how the social security situation in the current state of residence is. The FMEIA communicates the fact to the Ministry of Social Affairs, which, in turn, is in contact with the regions of Austria to find whether and where to place the person. The financial aspects of the takeover are decided upon on an individual basis taking insurance, assets, income and relatives into account. ${ }^{39}$ The policy was renamed in order to clarify that Austrians abroad do not have any legal entitlement to be repatriated.

Persons who emigrated between March 1933 and March 1945 due to serious reasons related to the Nazi regime can be entitled to care allowance if they draw victim relief benefits or an Austrian pension (see details under Sect. 2.3.3). Austrian representations assist persons with regard to the forms and contacts to the medical examination which is required for the application. ${ }^{40}$

\subsubsection{Pensions}

Similarly to my previous discussion, Austria's engagement in the area of pensions beyond EU legislation is mostly limited to the provision of information and the signature of bilateral social security agreements. The Austrian pension insurance institution (Pensionsversicherungsanstalt, PVA) provides general information for Austrians abroad on its websites and has particular brochures for pensioners living abroad in several languages, e.g. English and French. Furthermore, Austrian pensioners abroad can always contact the headquarters of the pension insurance institution in Vienna if they have questions. In some destination countries, the PVA offers international consultation days, both in Austria and in the respective country (currently - inter alia - Germany and Switzerland), where also Austrian pensioners abroad can be offered individual consultation. ${ }^{41}$ These consultation days are organized by the PVA and the pension institution of the respective other country. ${ }^{42}$

\footnotetext{
${ }^{39}$ Bundesministerium für Europa, Integration und Äußeres (2019). AÖ Rückkehr nach Österreich in besonderen Notlagen. https://www.bmeia.gv.at/reise-aufenthalt/leben-im-ausland/gesundheit-undsoziales/aoe-rueckkehr-nach-oesterreich-in-besonderen-notlagen/. Accessed 24 February 2019.

${ }^{40}$ Österreichische Botschaft Washington (2019). Pension \& Sozialangelegenheiten. http://botschaft. austria.org/pensionen-soziales/. Accessed 24 February 2019.

${ }^{41}$ Pensionsversicherungsanstalt (2019). Information für im Ausland lebende Pensionisten und Pensionistinnen. Wien: Pensionsversicherungsanstalt.

${ }^{42}$ Pensionsversicherungsanstalt (2019). Internationale Beratungstermine in Österreich 2018. https://www.pensionsversicherung. at/cdscontent/load?contentid=10008.664524\&vers ion=1543396677. Accessed 24 February 2019; Pensionsversicherungsanstalt (2019). Internationale Sprechtage mit Beteiligung der Pensionsversicherungsanstalt 2018. https://www. pensionsversicherung. at/cdscontent/load? contentid $=10008.665244 \&$ version $=1549953863$. Accessed 24 February 2019.
} 
Austrian pensions can be exported ${ }^{43}$ and, to do so, Austrians living abroad need to submit a life certificate once a year to the Austrian pension insurance institution which can be certified by the relevant Austrian representation. The PVA sends out this certificate to Austrians abroad in January and Austrians abroad need to return it within 6 weeks. If they have not received it by the end of February, they can also print the document (available on the website of the PVA), have it certified and send it back to the PVA. In order to be certified the life certificate, Austrians abroad can present themselves in person to the responsible representation (embassy, consulate general, honorary consul) and prove their identity (or to an official authority of the place of their residence or a notary public). If persons are not able to present themselves to the consulate due to age or sickness, the latter can also - provided that this can be performed without a lot of effort - come to the persons. ${ }^{44}$ Exceptions from this rule can be made in Germany: pensioners living in Germany can be paid out the pension in cash via the German post office. In this case, they do not need to submit the yearly life certificate. Beside the old-age pension, Austrians abroad can also draw invalidity pension, widow's/widower's pension or orphan's pension. ${ }^{45}$

Beyond the EU legal framework, Austria has a range of bilateral social security agreements with other countries that allow for periods of contributions in both countries to be taken into account in the calculation of their pension. For instance, the agreement with the US stipulates that periods of insurance in the other country can be added if an insurance period of at least 18 months in the US (if the application is made in the US) or of at least 12 months in Austria (if the application is made in Austria) can be met.

Due to its history, Austria grants special assistance, i.e. victim relief benefits, to persons who suffered under the Nazi regime (also their widows/widowers, orphans, partners and parents may be entitled to these benefits). In order to be eligible, persons need to have been an Austrian citizen on 13 March 1938 and subject to bodily harms or serious disadvantages under the Nazi regime. Disadvantages may be due to active resistance against the regime or due to the political beliefs, religion, or physical disabilities within the period between 6 March 1933 and 9 May 1945, for instance if the persons had to wear a Jewish badge ${ }^{46}$ (Judenstern) ${ }^{47}$

\footnotetext{
${ }^{43}$ The supplementary pension, Ausgleichszulage, however, cannot be exported.

${ }^{44}$ Bundesministerium für Europa, Integration und Äußeres (2019). Life Certificate. https://www. bmeia.gv.at/en/travel-stay/living-abroad/documents-civil-status-family/life-certificate/. Accessed 24 February 2019; Pensionsversicherungsanstalt (2018). Lebensbestätigung. http://www.pensionsversicherung.at/portal27/pvaportal/content/contentWindow?contentid=10007.707694\&act ion=2. Accessed 24 February 2019.

${ }^{45}$ Pensionsversicherungsanstalt (2019). Information für im Ausland lebende Pensionisten und Pensionistinnen. Wien: Pensionsversicherungsanstalt.

${ }^{46}$ The Jewish badge (Judenstern) was the badge that Jews had to wear under the Nazi regime.

${ }^{47}$ Österreichische Botschaft Washington (2019). Pension \& Sozialangelegenheiten. http://botschaft. austria.org/pensionen-soziales/. Accessed 24 February 2019.
} 


\subsubsection{Family-Related Benefits}

In general, in order to draw Austrian family benefits, one's "centre of interest" (Mittelpunkt der Lebensinteressen) has to be in Austria, implying for instance that the main residence of a person is in Austria (cf. § 2 Familienlastenausgleichsgesetz). ${ }^{48}$ This excludes Austrians abroad from the entitlement to family benefits. Also, besides the agreement with Israel, bilateral social security agreements signed by Austria do not include provisions on family benefits. Yet, it should be noted that a small supplementary child benefit (Kinderzuschuss) can be received by persons who draw an Austrian pension for every child under the age of $18 .{ }^{49}$

With regards to family-related administrative services, Austrian representations can issue a birth certificate provided that the necessary data is already recorded in the central civil registry (Zentrales Personenstandsregister). To do so, Austrians abroad need to fill out the respective form (available online), bring it to the representation and prove their identity. ${ }^{50}$

\subsubsection{Economic Hardship}

The general minimum welfare scheme for Austrians, minimum subsistence benefits (Bedarfsorientierte Mindestsicherung) as well as the supplementary pension (Ausgleichszulage) for pensioners, cannot be exported. However, there is a special fund for Austrians abroad in cases of financial hardship, the Fund for the Support of Austrian Citizens Abroad (Auslandsösterreicher-Fonds), to which both the FMEIA and the regions of Austria contribute to. Austrians abroad who find themselves in serious difficulties can apply for support out of the Fund. The assistance can be granted once or periodically depending upon whether the person faces a temporary emergency or permanent financial hardship. It is considered as a form of supplementary assistance, as an equivalent to the means-tested social benefits in Austria.

\footnotetext{
${ }^{48}$ Bundesministerium für Frauen, Familien und Jugend (2019). Anspruchsvoraussetzungen für die Familienbeihilfe. https://www.bmfj.gv.at/familie/finanzielle-unterstuetzungen/familienbeihilfe0/ anspruchsvoraussetzung.html. Accessed 24 February 2019.

${ }^{49}$ This supplementary benefit amounts to $29.07 €$ in 2019; Bundesministerium Digitalisierung und Wirtschaftsstandort (2019). Kinderzuschuss bei Alters-, Berufsunfähigkeits-, Invaliditäts- und Erwerbsunfähigkeitspension. https://www.help.gv.at/Portal.Node/hlpd/public/content/27/Seite. 270223.html. Accessed 24 February 2019; Pensionsversicherungsanstalt (2019). Information für im Ausland lebende Pensionisten und Pensionistinnen. Wien: Pensionsversicherungsanstalt.

${ }^{50}$ Bundesministerium Digitalisierung und Wirtschaftsstandort (2019). Neuausstellung einer Geburtsurkunde oder internationalen Geburtsurkunde. https://www.help.gv.at/Portal.Node/hlpd/ public/content/8/Seite.085100.html\#ZustaendigeStellen. Accessed 24 February 2019.
} 
The fund was established against the background of the Second World War and its related expulsions when many Austrians left respectively had to leave Austria settling also in countries which do not have a social system comparable to Austria where, for instance, pensions are smaller. Since 2007, also "Austrians at heart", i.e. former Austrian nationals or their children, can become eligible for the Fund. This reform sought to assist persons who, de facto, lost their Austrian citizenship because they had to adopt the nationality of the country of residence, or those who had to leave Austria under the Nazi regime.

In order to receive assistance, Austrians abroad need to file an application, in which they describe their individual situation of hardship, with the relevant Austrian representation. The application is, in a first step, assessed by employees of the relevant representation, because they can speak the language and know about the specific living conditions in the country and can thus determine whether the applicant actually faces a situation of hardship. In case the Austrian representation considers the applicant as eligible, the case is, in a second step, sent to the FMEIA respectively the Fund which assesses it again. The assistance is only granted if the person does neither have enough own income or assets that can be exploited nor funding by relatives who are obliged to support the person in terms of living costs. There is no obligation for reimbursement. ${ }^{51}$ In total, around $600,000 €$ were paid out per year between 2015 and 2017. ${ }^{52}$ According to the response to a query of Members of Parliament from 2012, the money provided by the FMEIA and the regions of Austria was sufficient in order to support all persons who applied for help and who met the criteria. ${ }^{53}$ In general, the share of Austrians abroad who (have to) make use of the financial support is small: out of 565,000 Austrians living abroad, only around 1100 persons receive assistance out of the fund..$^{54}$

Besides the Fund, the FMEIA also has an annual Christmas campaign for Austrians abroad in need: every December, it collects money and in-kind donations

\footnotetext{
${ }^{51}$ Bundesministerium für Europa, Integration und Äußeres (2019). Fund for the Support of Austrian Citizens Abroad. https://www.bmeia.gv.at/en/travel-stay/living-abroad/meeting-point-austriansabroad/fund-for-the-support-of-austrian-citizens-abroad/. Accessed 24 February 2019; Bundesministerium für Europa, Integration und Äußeres (2019). Auslandsösterreicher-Fonds (AÖF). Richtlinien für die Zuwendungen. https://www.bmeia.gv.at/fileadmin/user_upload/ Zentrale/Reise_Aufenthalt/AOE_Fonds_Zuwendungsrichtlinien.pdf. Accessed 24 February 2019.

${ }^{52}$ Bundesministerium für Finanzen (2018). Unterstützung bedürftiger österreichischer Staatsbürger im Ausland (Auslandsösterreicher Fonds). https://transparenzportal.gv.at/tdb/tp/leistung/1005164. html. Accessed 24 February 2019.

${ }^{53}$ Nationalrat (2012). 9977/AB XXIV. GP - Anfragebeantwortung. https://www.parlament.gv.at/ PAKT/VHG/XXIV/AB/AB_09977/imfname_242865.pdf. Accessed 24 February 2019.

${ }^{54}$ This number is confirmed by the FMEIA in March 2019. Bundesministerium für europäische und internationale Angelegenheiten (2010). Außenpolitischer Bericht 2009. Bericht des Bundesministers für europäische und internationale Angelegenheiten. Wien: Bundesministerium für europäische und internationale Angelegenheiten, p. 176.
} 
for Austrians abroad. ${ }^{55}$ These donations are distributed amongst Austrians abroad according to the personal situation of the latter and the specific conditions of the country of residence - based upon information of the Austrian missions. In exceptional cases, also the regions grant financial assistance to Austrians abroad who face financial difficulties. This is regulated by the relevant departments of the regional governments. ${ }^{56}$

\subsection{Conclusions}

The chapter on Austria demonstrated that in particular the special history of Austria and dominant interests of Austrians abroad can explain Austrian diaspora policies and social protection. In this final section, the principles of Austrian diaspora policies and social protection, as elaborated upon in the precedent sections, will be summed up again.

In general, Austrian diaspora policies are characterized by the principle of "help for self-help" and the link to Austria(n culture). Austria has undertaken a range of steps in order to make it easier for Austrians abroad to interact with Austrian authorities and to receive documents abroad. Documents such as passports, birth certificates or life certificates can be issued respectively certified by the relevant Austrian representation. Moreover, Austrians abroad can enter into contact with authorities online or even via the mobile phone signature within the EU. Furthermore, the link to Austria and Austrian culture has a high priority as the existence of the Kulturforen and the missions of the associations abroad demonstrate. Austrian representations seek to help and assist Austrians abroad, yet, the latter do for instance not have any legal entitlements to financial assistance.

The voting rights of Austrians abroad have been extended and the latter can nowadays cast a ballot in all national and some regional elections. This extension can be explained by the pressure via the Worldwide Association of Austrian Associations Abroad. Yet, the Worldwide Association of Austrian Associations Abroad described these achievements as a "long road" (Chlestil 2013). Austrians abroad are furthermore pushing for citizenship matters such as an extended possibility of dual citizenship, but less successfully.

\footnotetext{
${ }^{55}$ Bundesministerium für Europa, Integration und Äußeres (2015). Außen- und Europapolitischer Bericht 2015. https://www.bmeia.gv.at/fileadmin/user_upload/Zentrale/Publikationen/AEPB/ Aussen_und_Europapolitischer_Bericht_2015.pdf. Accessed 24 February 2019.

${ }^{56}$ Rechnungshof (2011). Bericht des Rechnungshofes. Auslandsösterreicher-Fonds. http://www. rechnungshof.gv.at/fileadmin/downloads/2011/berichte/teilberichte/bund/bund_2011_11/ Bund_2011_11_4.pdf. Accessed 24 February 2019.
} 
In terms of social security, beyond the extensive EU framework, the agreements between Austria and other countries mostly apply to pensions and the calculation of insurance periods. Only few agreements contain further rules, for instance on unemployment benefits. Home country institutions provide information and help establishing contacts such as doctors, solicitors or hospitals, and thus enable "help for self-help". In situations of economic hardship and exceptional circumstances, however, Austria takes further action. For Austrians abroad, Austria has special protection programmes: first and foremost, those who face serious financial difficulties can apply for (one-time or regular) support out the Fund for the Support of Austrian Citizens Abroad. Seriously ill or old Austrians abroad who can no longer provide for themselves can be brought into a hospital respectively an old persons' home in Austria. Austria thus seeks to guarantee a certain minimum living standard for its nationals abroad. These special social protection policies have to be understood in the light of Austrian history, the Austrian Anschluss and the Second World War, as a compensation for people who suffered under the Nazi regime.

Acknowledgements This chapter is part of the project "Migration and Transnational Social Protection in (Post)Crisis Europe (MiTSoPro)" that has received funding from the European Research Council (ERC) under the European Union's Horizon 2020 research and innovation programme (Grant agreement No. 680014). In addition to this chapter, readers can find a series of indicators comparing national social protection and diaspora policies across 40 countries on the following website: http://labos.ulg.ac.be/socialprotection/.

I am very grateful to the Office for Austrians Abroad and Digital Applications of Consular Citizens' Advice (Büro für AuslandsösterreicherInnen und digitale Anwendungen in der konsularischen BürgerInnenbetreuung, section IV.3 FMEIA) which provided me with further information on Austrian diaspora policies which were not accessible via documents or literature.

\section{References}

CARE Project. (2010). Consular and diplomatic protection. Legal framework in the EU member states. http://www.ittig.cnr.it/Ricerca/ConsularAndDiplomaticProtection.pdf. Accessed 24 Feb 2019.

Chlestil, G. (2013). Der lange Weg. https://www.austrians.org/magazin/article/6.498.858. Accessed 24 Feb 2019.

Mittelstaedt, K. (2016). ÖVP will E-Voting zuerst für Auslandsösterreicher. https://derstandard. at/2000044829326/OeVP-will-E-Voting-zuerst-fuer-Auslandsoesterreicher. Accessed 24 Feb 2019.

Neyer, G. (1995). Auswanderungen aus Österreich: Von der Mitte des 19. Jahrhunderts bis zur Gegenwart. Demographische Informationen 1995/96, 60-70.

Stern, J., \& Valchars, G. (2013). Access to electoral rights in Austria. http://cadmus.eui.eu/bitstream/handle/1814/29803/ER_2013_11-Austria-FRACIT.pdf?sequence=1. Accessed $24 \mathrm{Feb}$ 2019. 
Open Access This chapter is licensed under the terms of the Creative Commons Attribution 4.0 International License (http://creativecommons.org/licenses/by/4.0/), which permits use, sharing, adaptation, distribution and reproduction in any medium or format, as long as you give appropriate credit to the original author(s) and the source, provide a link to the Creative Commons license and indicate if changes were made.

The images or other third party material in this chapter are included in the chapter's Creative Commons license, unless indicated otherwise in a credit line to the material. If material is not included in the chapter's Creative Commons license and your intended use is not permitted by statutory regulation or exceeds the permitted use, you will need to obtain permission directly from the copyright holder. 